\title{
The Role of Farmer Field Schools Approach in Improving Tea Production among Smallholding in Kenya
}

\author{
Evans L. Chimoita ${ }^{1, *}$, Gatahi Dennis Maina ${ }^{2}$, Dennis Opiyo Olila ${ }^{1}$, Joseph P.Gweyi Onyango $^{3}$ \\ ${ }^{1}$ Department of Agricultural Economics, University of Nairobi, Kenya \\ ${ }^{2}$ Kenya Tea Development Agency, Kenya \\ ${ }^{3}$ Department of Agricultural Science and Technology, Kenyatta University, Kenya
}

Copyright (C) 2015 Horizon Research Publishing All rights reserved.

\begin{abstract}
Tea production, processing and marketing in Kenya is under management of two sectors. The two sectors include; Kenya Tea Development Agency which manages approximately six hundred thousand small scale farmers and multi-nationals sector for example Uniliver/Lipton teas, James Finlay's and George Williamson holdings manage privately plantations and estates of tea. The volume and frequency of plucking tea leaves enhances net revenue for small scale tea farmers in Kenya. The main objective was to determine the role of Farmer Field Schools extension approach and eventual outcome tea production among small scale farmers in Kenya. The study assessed the trends and the influence of Farmer Field Schools (FFS) approach in addressing productivity of tea leaves. The study employed descriptive statistics and mean trends analysis to determine the influence of FFS in tea production. The study sites were six sub locations of tea growing areas. The sites were purposively since they were pilot areas where the initial farmer field schools were collaboratively initiated by Kenya Tea Development Agency (KTDA) and Uniliver/Lipton teas for enhancement of tea production. The study gathered primary data from sampled tea farmers by use of structured questionnaires. Secondary data was sourced from the KTDA archives records. Research findings revealed a positive trend in green tea leaf production and as well as revenue. Further, it was revealed that social positive effects such as farmers willingness to participate in group activities and sustainable tea husbandry, promotion of self-mobilization and interactive participation enhanced tea production. The positive economic-agricultural productivity effects were; the transfer and adoption of agricultural technologies particularly in tea growing that enhanced revenue, increased access to knowledge and agricultural information.
\end{abstract}

Keywords Farmer Field Schools, Tea Green Leaf Yield, Tea Husbandry

\section{Introduction}

The tea industry in Kenya provides livelihood to over three million people along the value chain. The industry started in the first quarter of the $20^{\text {th }}$ century in Kenya and has continued to increase in terms of production and total acreage [1].The World agriculture in the twenty-first century faces three main challenges: assurance of food security, rural livelihoods and income as well as conserving and protecting natural resources [2].The World Food Summit and the Millennium Development Goals (MDGs) have been devising ways to mitigate against the aforementioned challenges. Agriculture is expected to assure food security in a range of settings, now and in the future, and is increasingly called upon to produce positive environmental, social, and economic benefits [3].

While agriculture is a key contributor to sustainable development, there is need in meeting the challenges facing producers. These challenges have led to paradigm shift for its primary producers in the context of a rapidly changing food economy and globalization [4]. These challenges can be tackled in part through a Good Agricultural Practices (GAP) approaches enhancing environmental, economic and through social sustainability of on-farm production. The resultant effects of GAP are safe and healthy food and non-food agricultural products [3].Tea is an evergreen under-storey shrub from the genus Camellia that includes some 82 species [5]. The tea species that is most important is Camellia spp, commercially and taxonomically cultivated to produce a stimulant brew. The two main varieties are Camellia sinensis var. assamica with relatively large, leaves, and Camellia sinensis with small semi-erect leaves. Assamica tea originated from the forests of Assam in north-eastern India and the sinensis tea from Sichuan province, south-western China [6]. The primary crop product consists of young tender leaves, which are withered, rolled, macerated, fermented, and dried to give different grades of teas for human consumption.

The KTDA and Lipton Sustainable Agriculture Project (LSAP) initiated a pilot move to increase the sustainability of tea production by increasing the rate of adoption of Good GAPs [7]. In the year 2006, the KTDA and Lipton initiated 
four pilot FFS in tea growing areas around four KTDA factories in Kenya. Green leaf production per tea bush is determined by assuming that one tea bush produces one kilogram of weighed two leaves and a bud per three to four plucking rounds per month [8].Under KTDA managed factories farms, FFS is an extension based approach which allow technologies and information transfer through interaction amongst farmers, extension assistants, experts and researchers in promoting sustainable agriculture and imparting skills that would otherwise have been impossible with the involvement of extension assistants alone in tea production.

It is also possible that the technologies promoted by FFSs do not act to change yields drastically, but rather improve income and net revenues among farmers. Further, FFS promotes value of production by reducing input costs and by reducing pesticide costs, provided these do not offset by any net increases in costs of labour in applying the new technologies and group market access [8].The World development report on agriculture, reports that extension services, after a period of neglect, are now back on the development agenda. More evaluation, learning, and knowledge sharing are required to capitalize on this renewed momentum. According to the International Academy Council [9], poverty reduction strategies in 24 African countries also listed extension as a top agricultural priority. It is for this approach (FFS) that the study investigated effects of GAP against tea production in Ngere tea zone in Murang'a County, Kenya

\section{Methodology}

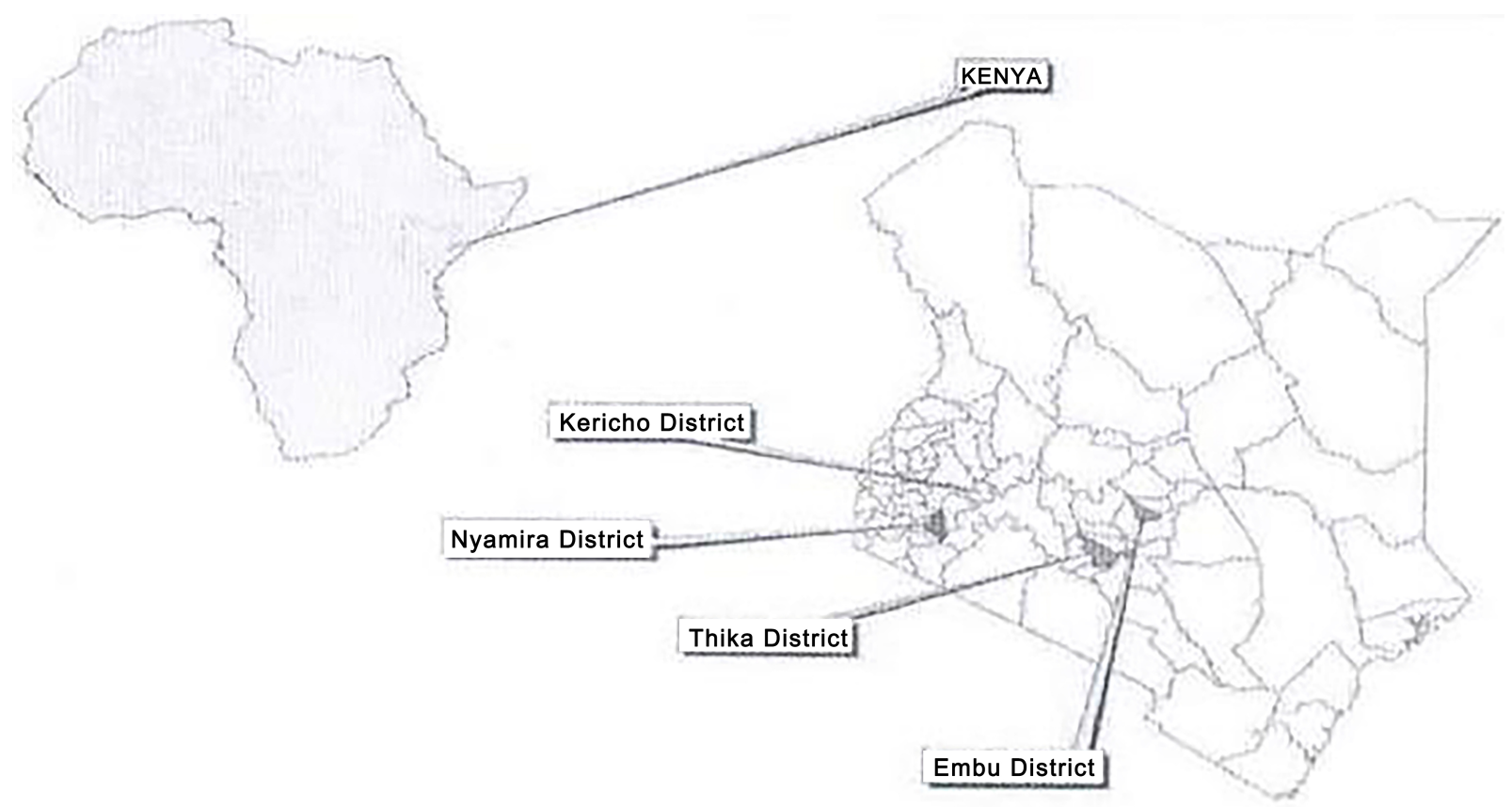

Figure 1. Initial KTDA FFS pilot implementation sites. Source: [7], KTDA and Lipton Unilever collaborative project

The study was conducted in Murang'a County. The site is one of the main acidic soil based tea growing areas along the Aberdare ranges of Kenya. The study was purposely conducted in tea growing area as one of the four pilot area FFS by KTDA and Lipton Uniliver project. The four pilot sites included Kericho, Nyamira, Thika and Embu districts of Kenya. Aberdare ranges are located in Thika as indicated on map (Figure 1).

The study randomly selected 50 out of 148 tea collection centres with known history of FFS training and activities implementation. The study employed stratified sampling technique to select tea farmers. The study therefore selected two farmers who had undergone FFS training from the available lists in the buying centres amounting to 100 farmers for study. Farmers were interviewed on arrange of Sustainable GAPs, such as, the level of green leaf production per tea bush, soil fertility and management, and Agribusiness and gender based decision making on smallholding.

The study acquired information through interview schedule concerning the farmer bio-data, knowledge on farmer field schools training and good agricultural practices. The study engaged the factory tea extension services assistants (T.E.S.A) to interview farmers. Further, a questionnaire was developed to capture information from Field Services Co-ordination (FSC) office to capture secondary evidence on variable levels of green leaf production. This was to provide documentary evidence of FFS training on sampled farmers in a period of four years (2008-2011).Data obtained from farmers' interview schedule and FSC questionnaire were analyzed using MS Excel package and Statistical Package for Social Scientists (SPSS). The data was analyzed to generate frequencies and tables providing descriptive results. 


\section{Results and Discussion}

The study revealed from field services coordination (FSC) department at Ngere KTDA managed factory that green leaf production per tea bush is one of the key performance indicators of good production and management in enhancing volumes of leaf production against good out turn revenue. Further, study reveals a tremendous increase of green leaf per bush production $(0.8 \mathrm{kgs}-1.2 \mathrm{kgs}$ per bush) in fiscal year $2005 / 2006$ to $2006 / 2007$ (Figure 2). This drastic increase was attributed to introduction and enhancement of farmer field schools (FFS) extension activities in Ngere tea growing area. However, there was noted decline in green leaf production per tea bush (0.7kgs) in the fiscal year $2007 / 2008$ as shown depicted in (Figure 2). The decline was attributed to decrease in volume of the green leaf harvested coupled with dry spell that affected the tea bushes.

\section{Production Data:}

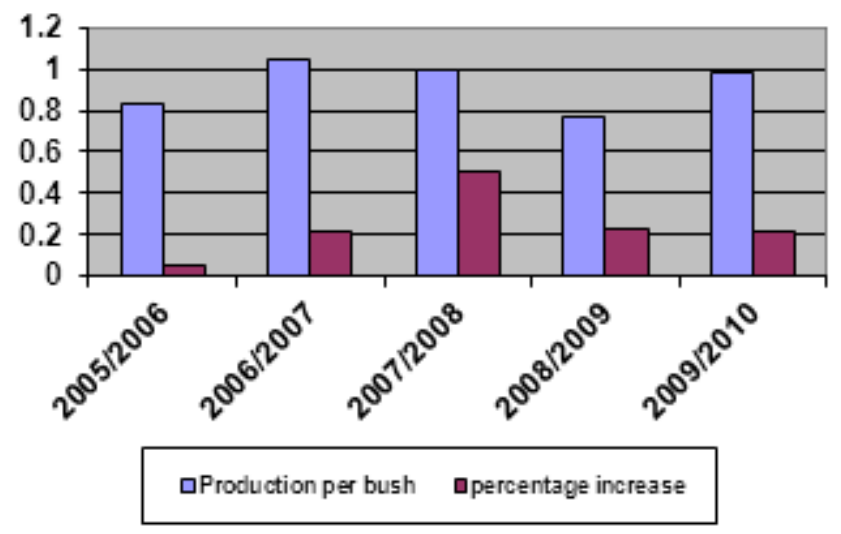

Figure 2. Green leaf production per tea bush $(\mathrm{N}=100)$

Moreover, the study sought to investigate the degree of implementation of good agricultural practices by farmers in
Ngere tea growing area. The resultant practices in (Figure 3), were rated on percentage implementation basing on the recommended principles in Tea growers hand book published by Tea Research Foundation of Kenya TRFK, [4].

Figure 3, depicts majority of the farmers (86\%) interviewed mentioned clearly the types of clones established on their farms. This is depicted further by mean trends analysis in appendix (Table 2). Moreover, $80 \%$ of the farmers indicated that they prune their tea bushes at recommended height of 20 "'inches above the ground to avoid Hypoxylon wood rot infection [10].

Further, it was revealed that $20 \%$ of farmers did not understand the importance of pruning heights clearly. This called for enhancement of FFS trainings and capacity building on pruning heights. However, a limited number of farmers interviewed (48\%) (Figure 3) indicated that they prune their tea bushes after a recommended period of 3-5 years, whereas the remaining (52\%) showed varied intervals which were inconsistent as per tea husbandry practices [11]. This is depicted further by mean trends analysis in appendix (Table 1).

It was apparent that $90 \%$ (Figure 3) of the farmers concurred to using improvised panga to prune their tea bushes while 10\% (Figure 3) used recommended pruning knives. This was attributed to the high cost and in-availability of recommended pruning knives to farmers. In addition, 46\% (Figure 3) of farmers use trained family members and FFS members to prune their tea bushes. This is depicted further by mean trends analysis in appendix (Table 5). However, $20 \%$ indicated that they employ non-trained non-family members to prune their tea bushes at an affordable pay whereas $14 \%$ used trained and non-family members to prune their tea bushes. This however called for enhancement of FFS training [12] as illustrated by mean trends analysis in appendix (Table 5).

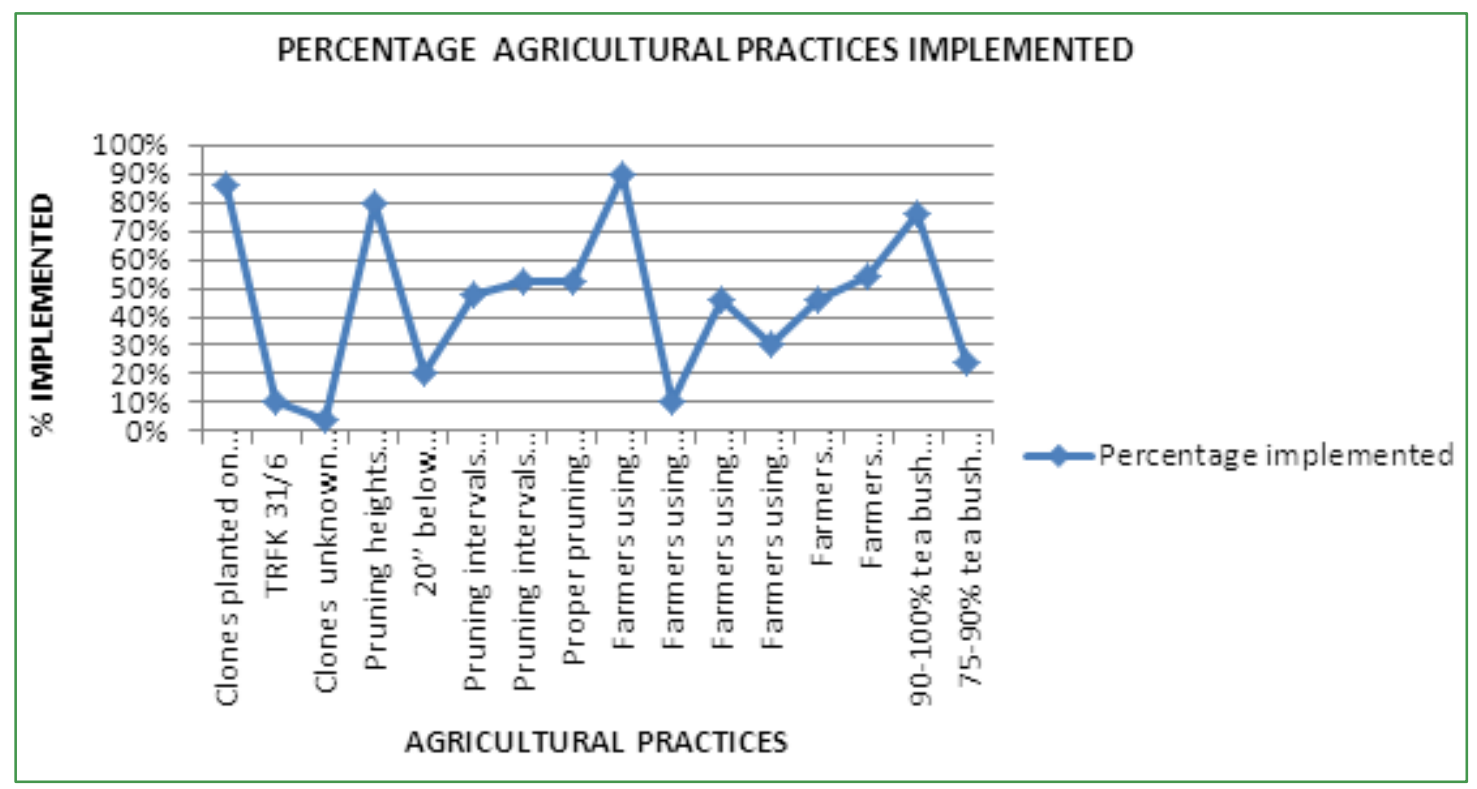

Figure 3. Percentage Agricultural Practices implemented, $N=100$ 


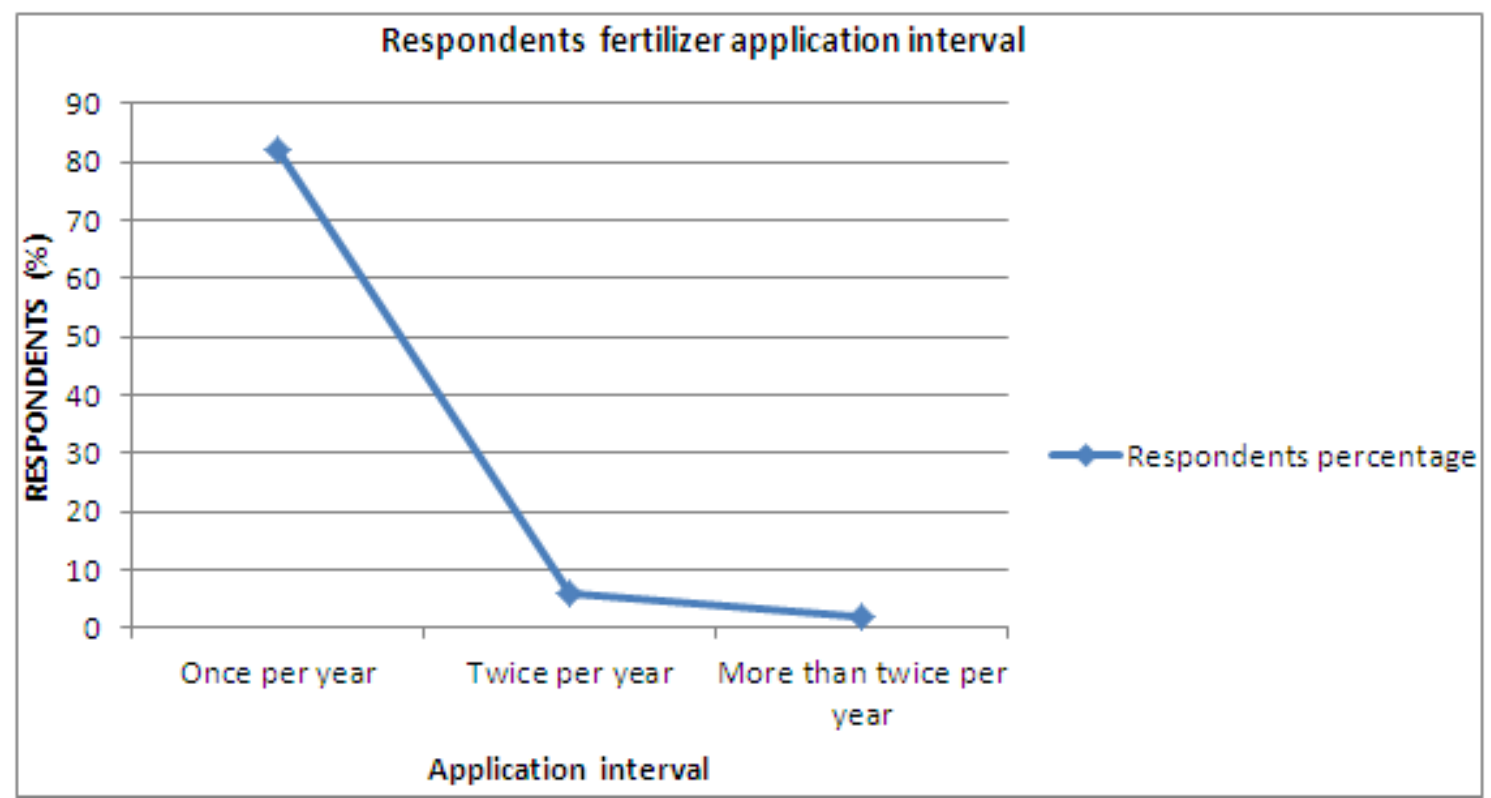

Figure 4. Interval of fertilizer application on farms $\mathrm{N}=100$

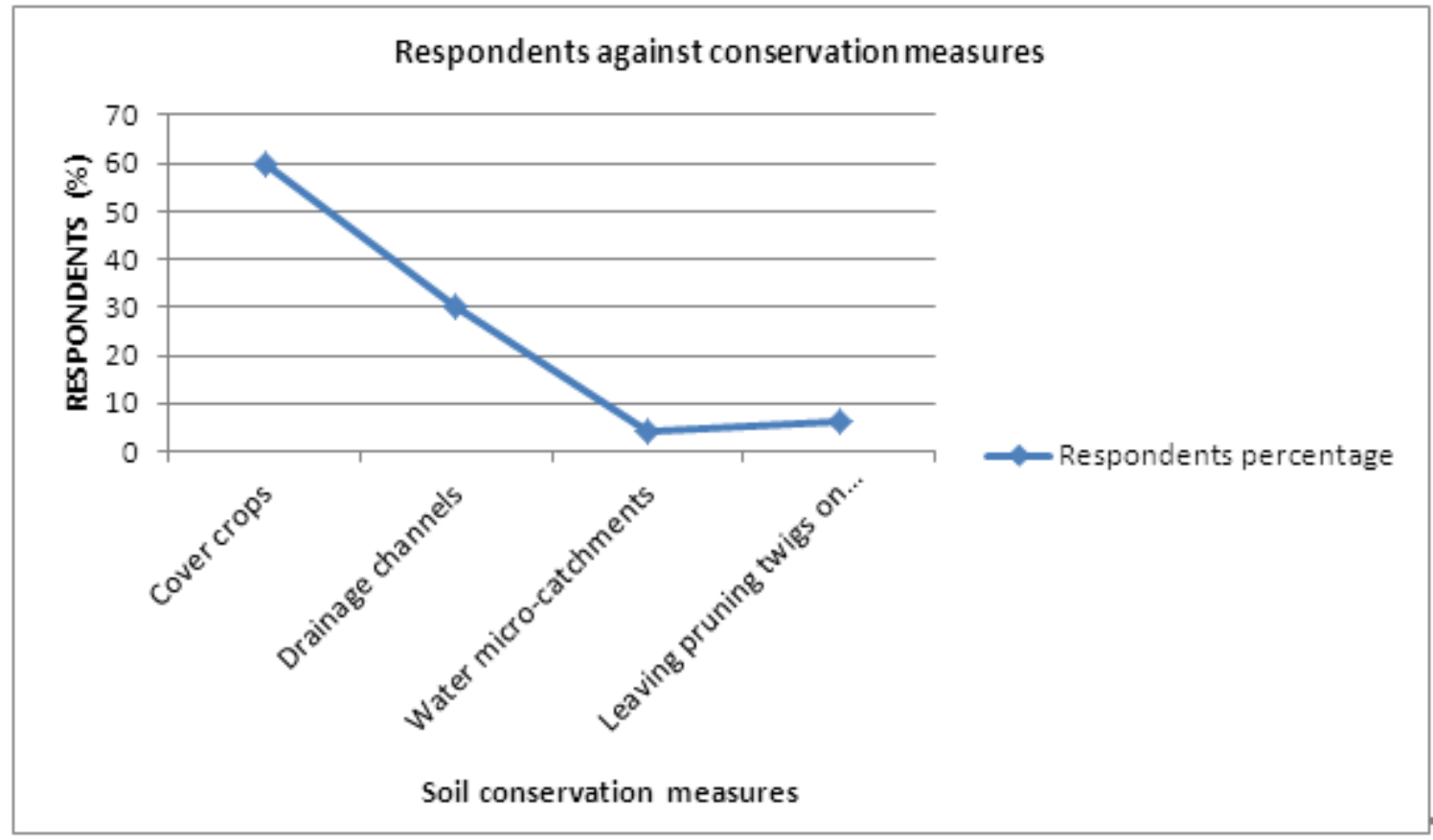

Figure 5. Soil moisture conservation measures among farmers, $\mathrm{N}=100$

In investigating the apparent increase in green leaf production per bush in Ngere tea growing area, the study sought to establish the contribution of fertilizer in increasing soil fertility and eventual increase in leaf production among other factors (Figure 4) [13]. The study revealed that $80 \%$ applied recommended NPK fertilizer as depicted by mean trends analysis in appendix (Table 1). The study found out that, manure in Ngere area is expensive commodity and in most cases, it is used on other horticultural activities that are more income generating than tea production [14].

The study further interviewed farmers to understand the utility of inorganic fertilizer NPK 25:5:5 procured and supplied to them by KTDA. It was revealed that $82 \%$ (Figure 4) applied NPK 25:5:5 fertilizer on their tea bushes once a year while a minimal number of farmers representing $6 \%$ (Figure 4) indicated that they applied twice per year and $2 \%$ applied more than twice per year respectively. This practice is in resonance with [15] and as illustrated by mean trends analysis in appendix (Table 1).

In the study, it was prudent to understand other practices done on the farms to promote sustainable agriculture. It was noted that $60 \%$ (Figure 5) of the farms had incorporated cover crops on their tilled farms, while $30 \%$ of farms had drainage channels and a number of farms were reducing the speed of rain water runoff by applying tea pruning twigs in water ways [16]. In addition, $8 \%$ (figure 5) of the farmers indicated that they leave tea pruning twigs on the farm so as to increase the soil nutrients for the sake of tea green leaf 
production and as illustrated by mean trends analysis in appendix (Table 4). This was a positive indication that through FFS farmers were knowledgeable on sustainable soil moisture conservation aspects [17].

The general crop cover and canopy is important factor in determining the volume of green production per hectare. The study unearthed that in Ngere tea growing area, $64 \%$ of the farms were practicing gaps in filling in the tea bushes, whereas 20 (Figure 5) of the farms observed showed no infillings and $18 \%$ of the farms observed a good canopy and suitable firm tea table. This is further illustrated by mean trends analysis in appendix (Table 3 ).

The study sought to understand farmer's availability on the farms in terms gender. Based on Figure 6, majority of the male farmers were readily available to divulge information than female farmers. It was worth noting that female farmers were readily available on the farms and home in Karangi and Gatura areas

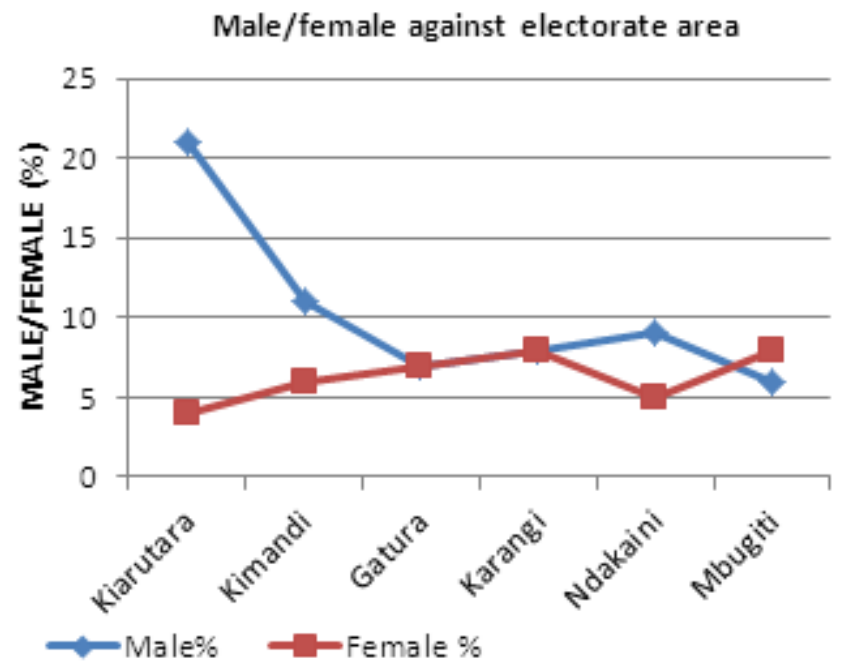

Name of electorate area

Figure 6. Soil moisture conservation measures among farmers, $\mathrm{N}=100$

In addition, study sought to understand the farm sizes and holdings in Ngere Tea growing area. It was apparent that majority of the farmers (80\%) (Figure 7) were indeed small scale farmers with approximate acreage of less than one acre and a significant number of $12 \%$ (Figure 7 ) owning less than ten acres of land under tea production. This justified the fact that Ngere tea growing area is representative of other small scale catchments managed by KTDA.
Percentage respondents against acreage size

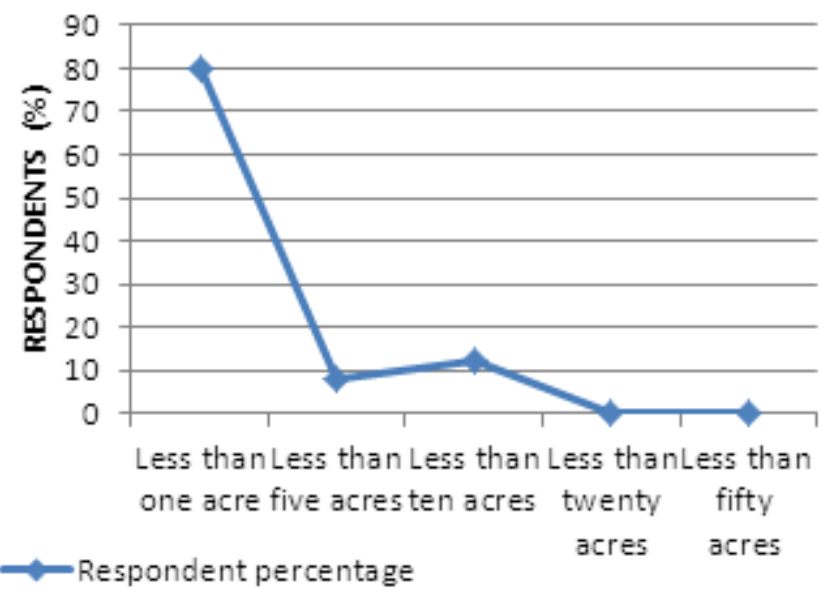

Approximate acreage

Figure 7. Farm sizes $(\mathrm{N}=100)$

\section{Summary, Conclusion and Recommendations}

It was revealed that the most farmers propagate mixed tea clones and TRFK $31 / 8$ clones on their farms, which is in tandem with region's ecological factors. Most of the farms were practicing gaps in filling in the tea bushes and as a result, a good tea bush canopy and suitable firm tea table was realized. It was revealed that there were drastic increasing trends in quantity of green leaf production per bush in tea in the region. The drastic increase was attributed to tea growing farmers embracing good agricultural practices facilitated by current Farmer Field Schools (FFS) extension methodology. The other positive social effects generated by FFS training includes; willingness to participate in group activities and marketing, promotion of self-mobilization and best tea husbandry techniques. The positive economic-agricultural productivity effects were; transfer and adoption of agricultural technologies particularly in tea growing that enhanced revenue, increased access to knowledge and agricultural information, embraced farming as a business.

The study recommends that due to positive impact by FFS to farmers, the government of Kenya should be replicate the FFS approach to other tea growing areas for positive effects in green leaf production and revenue from tea business. The study therefore envisages that such a noble intervention has the ability to enhance tea production besides improving the economic welfare of tea farmers. 


\section{Appendices}

Table 1. Mean analysis of fertilizer application trends versus production between years 2005 to 2010

\begin{tabular}{|c|c|c|c|c|c|c|}
\hline \multicolumn{2}{|c|}{ Fertilizer application interval } & $\begin{array}{c}\text { Bush } \\
\text { production } \\
2005 / 2006 \text { in } \\
\text { Kgs }\end{array}$ & $\begin{array}{c}\text { Bush } \\
\text { production } \\
2006 / 2007 \text { in } \\
\text { Kgs }\end{array}$ & $\begin{array}{c}\text { Bush } \\
\text { production } \\
2007 / 2008 \text { in } \\
\text { Kgs }\end{array}$ & $\begin{array}{c}\text { Bush } \\
\text { production } \\
2008 / 2009 \text { in } \\
\text { Kgs }\end{array}$ & $\begin{array}{c}\text { Bush } \\
\text { production } \\
2009 / 2010 \text { in } \\
\text { Kgs }\end{array}$ \\
\hline $\begin{array}{c}\text { Mixed } \\
\text { application }\end{array}$ & Mean & 1.28 & 1.28 & 1.29 & 1.29 & 1.30 \\
\hline $\begin{array}{l}\text { More than twice } \\
\text { per year }\end{array}$ & Mean & 1.47 & 1.47 & 1.48 & 1.48 & 1.48 \\
\hline Once per year & Mean & 1.20 & 1.21 & 1.20 & 1.20 & 1.21 \\
\hline Twice per year & Mean & 1.23 & 1.23 & 1.24 & 1.24 & 1.25 \\
\hline Total & Mean & 1.21 & 1.22 & 1.22 & 1.22 & 1.22 \\
\hline
\end{tabular}

Table 2. Mean analysis of clones planted by farmers and production trends in the years 2005 to 2010

\begin{tabular}{|c|c|c|c|c|c|c|}
\hline Type of clones & & $\begin{array}{c}\text { Bush } \\
\text { production }\end{array}$ & $\begin{array}{c}\text { Bush } \\
\text { production }\end{array}$ & $\begin{array}{c}\text { Bush } \\
\text { production }\end{array}$ & $\begin{array}{c}\text { Bush } \\
\text { production }\end{array}$ & $\begin{array}{c}\text { Bush } \\
\text { production }\end{array}$ \\
\hline Established & & $\begin{array}{c}2005 / 2006 \text { in } \\
\mathrm{Kg}\end{array}$ & $\begin{array}{c}2006 / 2007 \text { in } \\
\mathrm{Kg}\end{array}$ & $\begin{array}{c}2007 / 2008 \text { in } \\
\mathrm{Kg}\end{array}$ & $\begin{array}{c}2008 / 2009 \text { in } \\
\mathrm{Kg}\end{array}$ & $\begin{array}{c}2009 / 2010 \text { in } \\
\mathrm{Kg}\end{array}$ \\
\hline Unknown clones & Mean & 1.21 & 1.22 & 1.22 & 1.22 & 1.23 \\
\hline Mixed clones & Mean & 1.30 & 1.30 & 1.31 & 1.31 & 1.32 \\
\hline TRFK $31 / 6$ & Mean & 1.17 & 1.17 & 1.18 & 1.19 & 1.19 \\
\hline Total & Mean & 1.21 & 1.22 & 1.22 & 1.22 & 1.23 \\
\hline
\end{tabular}

Table 3. Mean analysis of percentage tea canopy cover versus production trends

\begin{tabular}{|c|c|c|c|c|c|c|}
\hline Canopy cover & & $\begin{array}{c}\text { Bush } \\
\text { production } \\
2005 / 2006 \text { in } \\
\text { Kgs }\end{array}$ & $\begin{array}{c}\text { Bush } \\
\text { production } \\
2006 / 2007 \text { in } \\
\text { Kgs }\end{array}$ & $\begin{array}{c}\text { Bush } \\
\text { production } \\
2007 / 2008 \text { in } \\
\text { Kgs }\end{array}$ & $\begin{array}{c}\text { Bush } \\
\text { production } \\
2008 / 2009 \text { in } \\
\text { Kgs }\end{array}$ & $\begin{array}{c}\text { Bush } \\
\text { production } \\
2009 / 2010 \text { in } \\
\text { Kgs }\end{array}$ \\
\hline Tea cover $75-90 \%$ & Mean & 0.96 & 0.96 & 0.96 & 0.97 & 0.97 \\
\hline Tea canopy $90-100 \%$ & Mean & 1.30 & 1.30 & 1.31 & 1.31 & 1.32 \\
\hline $\begin{array}{c}\text { Tea canopy } \\
\text { Total }\end{array}$ & Mean & 1.21 & 1.22 & 1.22 & 1.22 & 1.23 \\
\hline
\end{tabular}

Table 4. Mean analysis of soil conservation measures and production trends in the years 2005 to 2010

\begin{tabular}{|c|c|c|c|c|c|c|}
\hline \multicolumn{2}{|c|}{ Conservation measures } & $\begin{array}{c}\text { Bush } \\
\text { production } \\
2005 / 2006 \text { in } \\
\text { Kgs }\end{array}$ & $\begin{array}{c}\text { Bush } \\
\text { production } \\
2006 / 2007 \text { in } \\
\text { Kgs }\end{array}$ & $\begin{array}{c}\text { Bush } \\
\text { production } \\
2007 / 2008 \text { in } \\
\text { Kgs }\end{array}$ & $\begin{array}{c}\text { Bush } \\
\text { production } \\
2008 / 2009 \text { in } \\
\text { Kgs }\end{array}$ & $\begin{array}{l}\text { Bush production } \\
2009 / 2010 \text { in Kgs }\end{array}$ \\
\hline Cover crops & Mean & 1.17 & 1.17 & 1.18 & 1.18 & 1.18 \\
\hline Drainage channels & Mean & 1.27 & 1.27 & 1.28 & 1.28 & 1.28 \\
\hline $\begin{array}{l}\text { Leaving pruned } \\
\text { twigs on } \\
\text { the farm }\end{array}$ & Mean & 1.31 & 1.32 & 1.33 & 1.33 & 1.33 \\
\hline $\begin{array}{c}\text { Water } \\
\text { micr-catchments }\end{array}$ & Mean & 1.33 & 1.33 & 1.34 & 1.34 & 1.34 \\
\hline Total & Mean & 1.21 & 1.22 & 1.22 & 1.22 & 1.23 \\
\hline
\end{tabular}


Table 5. Mean analysis of effects of pruning labour versus production trends between 2005 and 2010

\begin{tabular}{|c|c|c|c|c|c|c|}
\hline Pruning personnel & & $\begin{array}{c}\text { Bush } \\
\text { production } \\
2005 / 2006 \text { in } \\
\text { Kgs }\end{array}$ & $\begin{array}{c}\text { Bush } \\
\text { production } \\
2006 / 2007 \text { in } \\
\text { Kgs }\end{array}$ & $\begin{array}{c}\text { Bush } \\
\text { production } \\
2007 / 2008 \text { in } \\
\text { Kgs }\end{array}$ & $\begin{array}{c}\text { Bush } \\
\text { production } \\
2008 / 2009 \text { in } \\
\text { Kgs }\end{array}$ & $\begin{array}{c}\text { Bush } \\
\text { production } \\
2009 / 2010 \text { in } \\
\text { Kgs }\end{array}$ \\
\hline Mixed pruners & Mean & 1.19 & 1.19 & 1.19 & 1.20 & 1.20 \\
\hline None trained pruners & Mean & 0.81 & 0.81 & 0.81 & 0.82 & 0.82 \\
\hline $\begin{array}{c}\text { Trained and non family } \\
\text { members }\end{array}$ & Mean & 1.21 & 1.22 & 1.23 & 1.23 & 1.23 \\
\hline $\begin{array}{c}\text { Trained family and FFS } \\
\text { members }\end{array}$ & Mean & 1.43 & 1.44 & 1.44 & 1.45 & 1.45 \\
\hline Total & Mean & 1.21 & 1.22 & 1.22 & 1.22 & 1.23 \\
\hline
\end{tabular}

\section{REFERENCES}

[1] TRFK. 1986. Tea Growers Handbook (4th Edition ed.). Nairobi: Elizer services Publishers.

[2] FAO. 1999. Food and Agriculture Association of the United Nations (FAO). Rome: Intent printers.

[3] Owour, P., Kavoi, M., \& Siele, D. 2005. Assessement of constraints in technology transfer and policies which limit the realization of high green leaf production in the smallholder tea sector of the Kenya tea Industry: An impirical analysis of economic effieciency and supply of tea.Nairobi, Kenya: University press.

[4] Anonymous. 1986. Tea Growers Handbook (4th Edition ed.). Nairobi: Elizer services Publishers.

[5] Banerjee, B., Willson, K., \& Clifford, M. 1992. Botanical classification of tea. Tea Cultivation to Consuption, 25-51.

[6] Zeiss, M., \& Dembraker, K. 2001. Growth and physiology of tea plant. Tea, IPM Ecological Guide, 30-37.

[7] Hiller, S., Onduru, D., \& De Jager, A. 2009. Sustainable Tea Production: An Assessement of Farmer field Schools. The Hague: Wageningen press.

[8] TRFK. 2002. Tea Research Foundation of Kenya: Tea
Growers Handbook (5th Edition Ed.) Kericho: University press.

[9] Inter-academy council, Report 2004

[10] Otieno, W. 2005. Basis of Good Agriculture Practices in Sustainable Crop Protection. Nairobi.

[11] Bore, J., njuguna, C., \& Magambo, M. 1998. Effect of high Population Densities on Harvest Index and Yield. Nairobi: University press.

[12] Ellis, R., and Grice, W. 1976. Plucking Policy and Techniques. TRFCA Quarterly Newsletter, 3-14

[13] Ng'etich, W., Itulya, F., Bore, J., \& Isutsa, D. 2003. Effects of Prunning time and resting period on total non-structural cabohydrates, regrowth and yield. Journal of Horticultural Science and Biotechnology, 78,272-277.

[14] Dang, M. 2005. soil plant nutrient balance of tea crops in the northern mountainous region,Vietnam. Agriculture, Ecosystems and Environment, 105, 413-418.

[15] Bonheure, D., \& Willson, K. 1992. Mineral Nutrition and Fertilizers. Tea Cultivation to Consumption , 269-329.

[16] Kimmins, J. 1996. Importance of soil and role of ecosystem disturbance for sustainable productivityof cool temperate forest. Soil Science of America Journal , 60, 1643-1654.

[17] Anderson, J., \& Ingram, J. 1996. Tropical Soil Biology and Fertility. Wallingford, UK: CAB 